\title{
An Extremely Stable Host-Guest Complex That Functions as a Fluorescence Probe for Calcium Ions
}

\author{
Chi-Feng Lin, ${ }^{[a]}$ Yi-Hung Liu, ${ }^{[a]}$ Chien-Chen Lai, ${ }^{[b]}$ Shie-Ming Peng, ${ }^{[a]}$ and \\ Sheng-Hsien Chiu*[a]
}

In memory of Tong-Ing Ho

\begin{abstract}
Herein, we report a crown ether based molecular cage that forms extremely stable supramolecular complexes with dimethyldiazapyrenium (DMDAP) ions in $\mathrm{CD}_{3} \mathrm{CN}$ through the collaboration of multiple weak C$\mathrm{H} \cdots \mathrm{O}$ hydrogen bonds. The very strong binding affinity in this host-guest system allows the molecular cage to bleach the fluorescence signal of
\end{abstract}

DMDAP substantially in equimolar solutions at concentrations as low as $1 \times 10^{-5}$ M. Remarkably, a $1 \times 10^{-5} \mathrm{M}$ equimolar solution of the molecular

Keywords: calcium • fluorescence • host-guest systems • molecular cages • sensors • supramolecular chemistry cage and DMDAP is highly selective toward $\mathrm{Ca}^{2+}$ ions-relative to other biologically important $\mathrm{Li}^{+}, \mathrm{Na}^{+}, \mathrm{K}^{+}$, and $\mathrm{Mg}^{2+}$ ions-and causes a substantial increase in the fluorescence intensity of the solution. As a result, this molecular cage/DMDAP complex behaves as a supramolecular fluorescence probe for the detection of $\mathrm{Ca}^{2+}$ ions in solution.

\section{Introduction}

Artificial optical sensors that respond selectively to biologically important metal ions (e.g., $\mathrm{Li}^{+}, \mathrm{Na}^{+}, \mathrm{K}^{+}, \mathrm{Mg}^{2+}$, and $\mathrm{Ca}^{2+}$ ) have attracted much attention for their potential use in chemical and biological applications. ${ }^{[1]}$ Because of the importance of ionic calcium in physiological processes, ${ }^{[2]}$ chemosensors that display specificity toward $\mathrm{Ca}^{2+}$ ions are in particular demand. ${ }^{[3]}$ Currently, most fluorescence detectors are prepared by covalently linking molecular receptors to fluorophores; signal processing is achieved through variation of the molecule's electronic nature ${ }^{[4]}$ or of the chromophore's properties ${ }^{[3 f, 5]}$ after association with the metal ion. Although indicator-displaceable ensembles ${ }^{[6]}$ and cyclodex-

[a] C.-F. Lin, Y.-H. Liu, Prof. S.-M. Peng, Prof. S.-H. Chiu Department of Chemistry, National Taiwan University No. 1, Sec. 4, Roosevelt Road, Taipei, Taiwan (ROC) Fax: (+886) 2-3366-1677 E-mail: shchiu@ntu.edu.tw

[b] Prof. C.-C. Lai

Department of Medical Genetics and Medical Research China Medical University Hospital, Taichung, Taiwan (ROC)

Supporting information for this article is available on the WWW under http://www.chemeurj.org/ or from the author. trin-based supramolecular host-guest systems ${ }^{[7]}$ have been applied in many elegant supramolecular sensing complexes, 1:1 host-guest mixtures have yet to be applied as fluorescence probes in submillimolar concentrations for the detection of trace amounts of $\mathrm{Ca}^{2+}$ ions. Part of the difficulty in developing supramolecular host-guest complexes that operate as optical sensors at low concentrations is that a very strong binding affinity must exist between the host and guest species to avoid a strong background signal from the fluorescent, free species. ${ }^{[8]}$ Herein, we report a crown ether based molecular cage ${ }^{[9]}$ that forms extremely stable supramolecular complexes with dimethyldiazapyrenium (DMDAP) ions in $\mathrm{CD}_{3} \mathrm{CN}$ through the collaboration of multiple weak $\mathrm{C}-\mathrm{H} \cdots \mathrm{O}$ hydrogen bonds. The very strong binding affinity in this host-guest system allows the molecular cage to substantially bleach the fluorescence signal of DMDAP in equimolar solutions at concentrations as low as $1 \times 10^{-5} \mathrm{M}$. Remarkably, a $1 \times 10^{-5} \mathrm{M}$ equimolar solution of the molecular cage and DMDAP is highly selective toward $\mathrm{Ca}^{2+}$ ions: the solution displays a substantial increase in its fluorescence intensity in the presence of $\mathrm{Ca}^{2+}$, but much less so in the presence of $\mathrm{Li}^{+}, \mathrm{Na}^{+}, \mathrm{K}^{+}$, or $\mathrm{Mg}^{2+}$ ions. As a result, this molecular cage/DMDAP complex behaves as a supramolecular fluorescence probe for the detection of $\mathrm{Ca}^{2+}$ ions in solution. 


\section{Results and Discussion}

Inspired by a jawlike ditopic [18]crown-6 (18C6) host that is capable of forming stable face-toface complexes with diammonium ions through multiple $\mathrm{N}^{+}-$ $\mathrm{H} \cdots \mathrm{O}$ hydrogen bonds ${ }^{[10]}$ and by the crown ether bis(para-phenylene)[34]crown-10 (BPP34C10), which forms a pseudorotaxanelike complex with DMDAP through aryl-aryl interactions and $\mathrm{C}-\mathrm{H} \cdots \mathrm{O}$ hydrogen bonds, ${ }^{[1]}$ we expected that the cage-like host 1 would form a very stable complex with DMDAP in solution, that is, one that would be stabilized through multiple weak $\mathrm{C}-\mathrm{H} \cdots \mathrm{O}$ hydrogen bonds between the methyl and $\alpha$-pyridinium protons of the DMDAP ion and the oxygen atoms of the triethylene glycol chains of molecular cage 1 (Figure 1 ). ${ }^{[12]}$ In addition, we expected that the capture of DMDAP within molecular cage $\mathbf{1}$ would quench the fluorescence emission of the DMDAP ion through intermolecular, radiationless, energy-transfer ${ }^{[13]}$ or charge-transfer ${ }^{[14]}$ processes, and we hoped that the addition of a metal ion to this solution would cause the dissociation of the complex $[\mathbf{1} \supset \mathrm{DMDAP}]^{2+}$ to release free DMDAP ions into solution with a concomitant increase in the fluorescence emission intensity of the mixture.

We synthesized molecular cage 1 from 2,3,6,7-tetrahydroxy-9,10-dimethyl-9,10-dihydro-9,10-ethanoanthracene $(2)^{[15]}$ in three steps (Scheme 1). The reaction of the biscate-

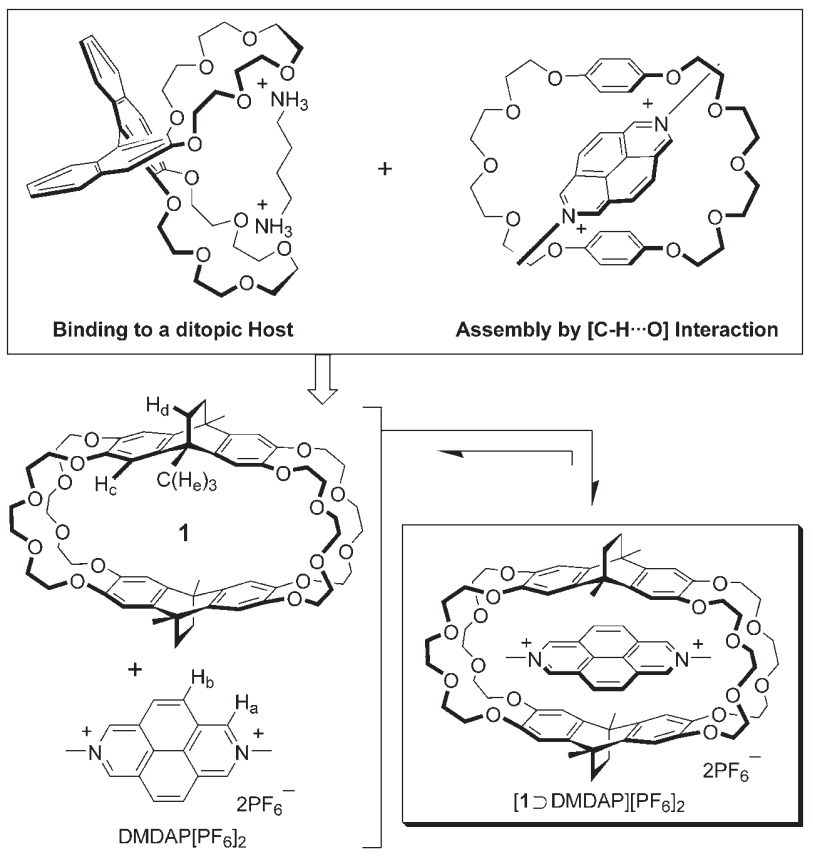

Figure 1. Design of molecular cage $\mathbf{1}$ for the complexation of DMDAP. chol 2 with triethyleneglycol monotosylate (3) under basic conditions gave the tetraol $\mathbf{4}$, which we then reacted with tosyl chloride to give the tetrakistosylate $\mathbf{5}$. The $[1+1]$ macrocyclization reaction of $\mathbf{5}$ and the biscatechol $\mathbf{2}$ gave the desired molecular cage $\mathbf{1}$ in $8 \%$ yield.

The ${ }^{1} \mathrm{H}$ NMR spectrum of an equimolar mixture of molecular cage 1 and DMDAP $\left[\mathrm{PF}_{6}\right]_{2}$ in $\mathrm{CD}_{3} \mathrm{CN}$ (4 mM) at room temperature displays significant changes in the chemical shifts of the protons of the complex relative to those of its free components (Figure 2). To confirm that the disappear-

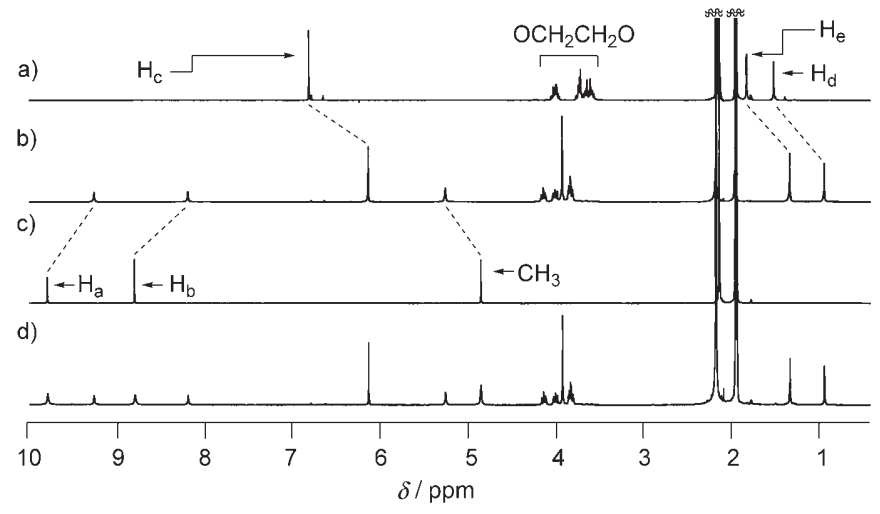

Figure 2. Partial ${ }^{1} \mathrm{H}$ NMR spectra (400 $\mathrm{MHz}, \mathrm{CD}_{3} \mathrm{CN}, 298 \mathrm{~K}$ ) of a) molecular cage $\mathbf{1}, \mathrm{b})$ an equimolar mixture of $\mathbf{1}$ and $\left.\mathrm{DMDAP}\left[\mathrm{PF}_{6}\right]_{2}(4 \mathrm{~mm}), \mathrm{c}\right)$ DMDAP $\left[\mathrm{PF}_{6}\right]_{2}$, and d) a mixture of $\mathbf{1}(4 \mathrm{~mm})$ and DMDAP $\left[\mathrm{PF}_{6}\right]_{2}$ (10 mM).

ance of the signals of the free species in the spectrum is due to complete complexation of both components, rather than being the result of fast rates of exchange in the complexation/decomplexation processes under these conditions, we used ${ }^{1} \mathrm{H}$ NMR spectroscopy to monitor a nonstoichiometric mixture of molecular cage $1(4 \mathrm{~mm})$ and DMDAP $\left[\mathrm{PF}_{6}\right]_{2}$ (10 mM) in $\mathrm{CD}_{3} \mathrm{CN}$; we observed two sets of signals, which integrated in a 2:3 ratio, with the stronger absorption set corresponding to the signals of the free DMDAP ions (Figure $2 \mathrm{~d}$ ). This observation suggests that the binding stoichi- 
ometry of the molecular cage $\mathbf{1}$ to DMDAP is 1:1 and that the exchange rates for their complexation and decomplexation are slow under these conditions. ${ }^{[16]}$ We did not observe any signals of the free species in the ${ }^{1} \mathrm{H}$ NMR spectra upon diluting an equimolar mixtures of molecular cage $\mathbf{1}$ and DMDAP $\left[\mathrm{PF}_{6}\right]_{2}$ from $1 \mathrm{~mm}$ to $10 \mu \mathrm{M}$ (Figure 3), suggesting that the binding between molecular cage $\mathbf{1}$ and DMDAP is extremely tight. ${ }^{[17]}$

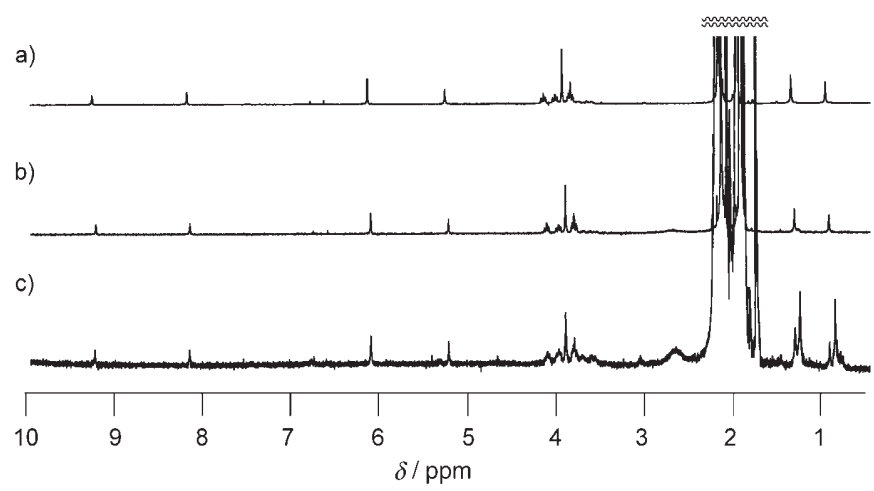

Figure 3. Partial ${ }^{1} \mathrm{H}$ NMR spectra $\left(400 \mathrm{MHz}, \mathrm{CD}_{3} \mathrm{CN}, 298 \mathrm{~K}\right.$ ) of equimolar mixtures of 1 and DMDAP $\left[\mathrm{PF}_{6}\right]_{2}$ at concentrations of a) 1, b) 0.1 , and c) $0.01 \mathrm{~mm}$.

The ${ }^{1} \mathrm{H}$ NMR spectra of the complex display a downfield shift for the signal of the protons of the methyl group of DMDAP and spreading of the protons of the ethylene glycol signals of molecular cage $\mathbf{1}$; these features suggest the possible existence of $\mathrm{C}-\mathrm{H} \cdots \mathrm{O}$ hydrogen bonds in the complex. ${ }^{[18]}$ The upfield shifts of the signals of the aromatic protons of both 1 (from $\delta=6.81$ to $6.14 \mathrm{ppm}$ ) and DMDAP (from $\delta=9.79$ and $8.79 \mathrm{ppm}$ to $\delta=9.26$ and $8.19 \mathrm{ppm}$, respectively) suggest possible shielding between the aromatic rings of the two components in the complex. These results support our proposed molecular geometry for complex $[(\mathbf{1} \supset \mathrm{DMDAP})]\left[\mathrm{PF}_{6}\right]_{2}$ (Figure 1).

We grew single crystals suitable for X-ray crystallography through liquid diffusion of isopropyl ether into an equimolar solution of molecular cage 1 and DMDAP $\left[\mathrm{PF}_{6}\right]_{2}$ in $\mathrm{CH}_{3} \mathrm{CN}$. The solid-state structure confirms the binding geometry in complex $[\mathbf{1} \supset \text { DMDAP }]^{2+}$ (Figure 4$),{ }^{[19]}$ in which fourteen C$\mathrm{H} \cdots \mathrm{O}$ hydrogen bonds formed between the methyl and $\alpha$ pyridinium protons of DMDAP and the oxygen atoms on the ethylene glycol chains of molecular cage 1. Although $\mathrm{C}-$ $\mathrm{H} \cdots \mathrm{O}$ hydrogen-bonding interactions are quite weak, the multiple copies of this weak interaction lead to a very stable complex [1 $\supset$ DMDAP $]^{2+}$ in solution.

Figure 5 provides a comparison of the emission spectra observed upon addition of molecular cage $\mathbf{1}$ to a solution of DMDAP $\left.\left[\mathrm{PF}_{6}\right]_{2}\left([\mathbf{1}]=\left[\mathrm{DMDAP}_{\mathrm{PF}_{6}}\right]_{2}\right]=1 \times 10^{-5} \mathrm{M}\right)$; it is clear that one equivalent of molecular cage 1 quenches the fluorescence of DMDAP substantially under these conditions. We monitored the fluorescence intensities of the supramolecular system in the presence of various metal ions. For $\mathrm{Li}^{+}, \mathrm{Na}^{+}, \mathrm{K}^{+}$, and $\mathrm{Mg}^{2+}$ ions, the fluorescence changes

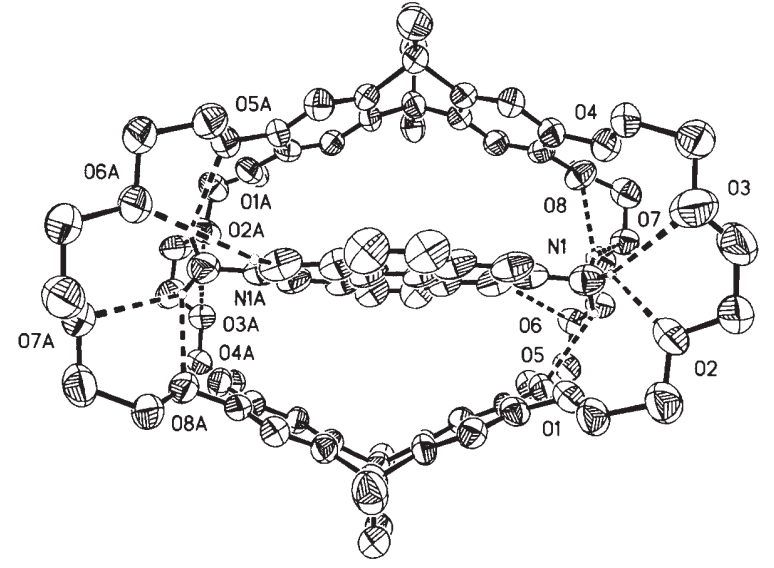

Figure 4. ORTEP plot of the solid state structure of $[1 \supset \mathrm{DMDAP}]^{2+}$. The dashed lines indicate intracomplex $\mathrm{C}-\mathrm{H} \cdots \mathrm{O}$ hydrogen bonds (see Supporting Information for the bond lengths and bond angles).

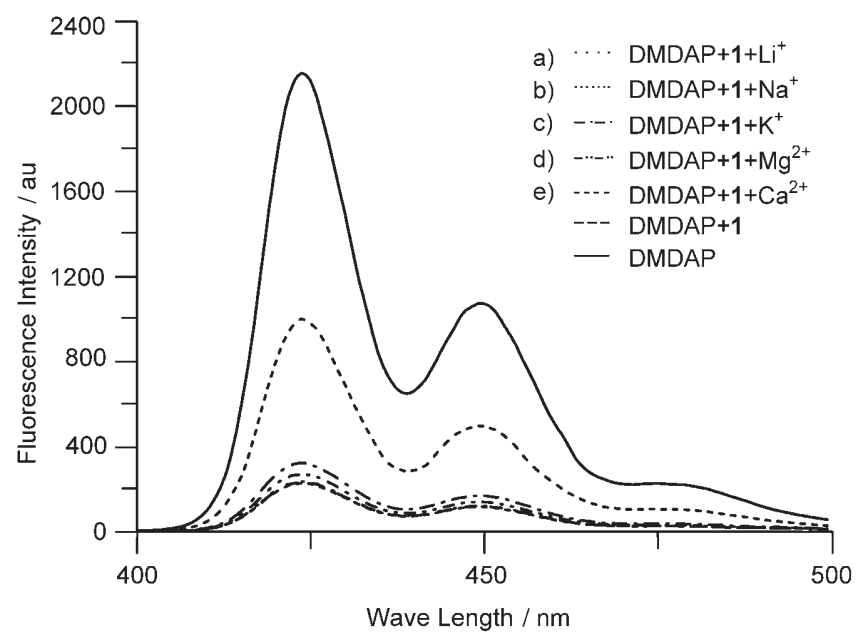

Figure 5. The corresponding fluorescence spectra $\left(\mathrm{MeCN}, 1 \times 10^{-5} \mathrm{M}\right.$, $298 \mathrm{~K}$; excitation at $247 \mathrm{~nm}$ ) of equimolar mixtures of $\mathbf{1}$, DMDAP, and a) $\mathrm{Li}^{+}$, b) $\mathrm{Na}^{+}$, c) $\mathrm{K}^{+}$, d) $\mathrm{Mg}^{2+}$, and e) $\mathrm{Ca}^{2+}$.

were much weaker than that observed for $\mathrm{Ca}^{2+}$ ions, suggesting that the interactions of the first four ions with molecular cage $\mathbf{1}$ are much weaker than those of the last one (Figure 5). The value of the fluorescence enhancement ratio $\left[\left(F-F_{0}\right) / F_{0}\right]$ after we had added one equivalent of $\mathrm{Ca}^{2+}$ ions to an equimolar mixture of molecular cage 1 and DMDAP$\left[\mathrm{PF}_{6}\right]_{2}\left(1 \times 10^{-5} \mathrm{M}\right)$ was at least ten times higher than those determined after the addition of the same amount of $\mathrm{Li}^{+}$, $\mathrm{Na}^{+}, \mathrm{K}^{+}$, and $\mathrm{Mg}^{2+}$ ions in the same solution (Figure 6); this result suggests that this molecular cage/DMDAP complex displays good selectivity toward $\mathrm{Ca}^{2+}$ ions among this set of biologically important metal ions. ${ }^{[20]}$

The ${ }^{1} \mathrm{H}$ NMR spectrum of a 2:1 molar ratio mixture of molecular cage $\mathbf{1}$ and $\mathrm{KPF}_{6}$ displayed a discernable shift in the signals of the ethylene glycol protons, but the shift seems to be quite different to the one in the spectrum of a mixture of $\mathbf{1}$ and $\mathrm{Ca}^{2+}$ (see Supporting Information); therefore, we suspected that the modes of complexation of mo- 


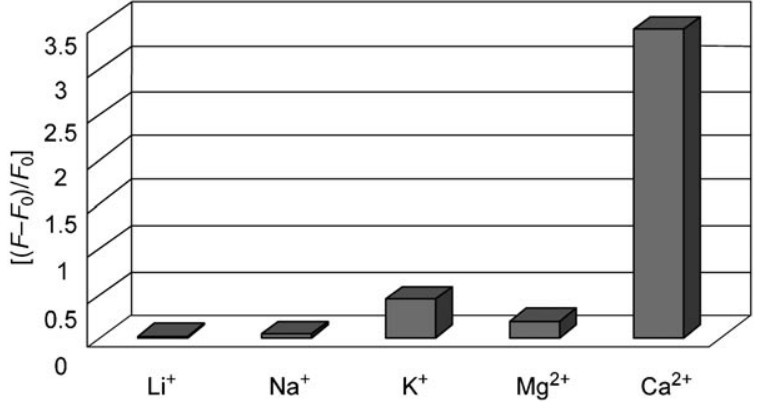

Figure 6. Fluorescence enhancement ratio profiles of a solution of $\mathbf{1}$ and DMDAP $\left(1 \times 10^{-5} \mathrm{M}\right.$ in $\left.\mathrm{MeCN}\right)$ in the presence of equimolar selected metal ions. Excitation was performed at $247 \mathrm{~nm}$; emission was monitored at $423 \mathrm{~nm}$.

lecular cage 1 to these two types of ions may be different. We grew single crystals suitable for X-ray crystallography through liquid diffusion of isopropyl ether into 1:2 molar ratio solutions of molecular cage 1 and $\mathrm{Ca}\left(\mathrm{ClO}_{4}\right)_{2}$ or $\mathrm{KPF}_{6}$ in $\mathrm{CH}_{3} \mathrm{CN}$. The solid-state structures reveal that the complexation of molecular cage $\mathbf{1}$ with $\mathrm{Ca}^{2+}$ ions utilized only one of the triethylene glycol chains of each crown ether moiety $^{[21]}$ (Figure 7), whereas the complex formed with the two $\mathrm{K}^{+}$ions involved the cooperation of all of the triethylene glycol loops ${ }^{[22]}$ (i.e., each $\mathrm{K}^{+}$ion was bound to all eight oxygen atoms of each crown ether unit; Figure 7). Because the complexation geometries of the molecular cage $\mathbf{1}$ to these metal ions involve either one or two triethylene glycol chains, it is not evident why $\mathbf{1}$ has a much stronger binding affinity toward $\mathrm{Ca}^{2+}$ ions than toward $\mathrm{Li}^{+}, \mathrm{Na}^{+}, \mathrm{K}^{+}$, or $\mathrm{Mg}^{2+}$ ions; presumably it results from a combination of effects including the size of the pseudocrown ether's cavity and the charge densities, sizes, and coordination numbers of the cations. ${ }^{[3 \mathrm{f}, 23]}$

\section{Conclusion}

We have demonstrated that the presence of multiple C$\mathrm{H} \cdots \mathrm{O}$ hydrogen-bonding interactions can lead to the formation of an extremely stable supramolecular complex between molecular cage $\mathbf{1}$ and DMDAP $\left[\mathrm{PF}_{6}\right]_{2}$. The strong binding affinity between these two species allows this complex to act as a fluorescence probe under dilute conditions $\left(1 \times 10^{-5} \mathrm{M}\right)$, in which $\mathrm{Ca}^{2+}$ ions respond highly selectively with respect to $\mathrm{Li}^{+}, \mathrm{Na}^{+}, \mathrm{K}^{+}$, and $\mathrm{Mg}^{2+}$ ions. This result suggests that supramolecular host-guest complexes can be used as efficient optical probes for detecting analytes at low concentrations, as long as the binding affinity between the host and guest is sufficiently strong, yet labile.

\section{Experimental Section}

General: All glassware, stirrer bars, syringes, and needles were either oven- or flame-dried prior to use. All reagents, unless otherwise indicat-
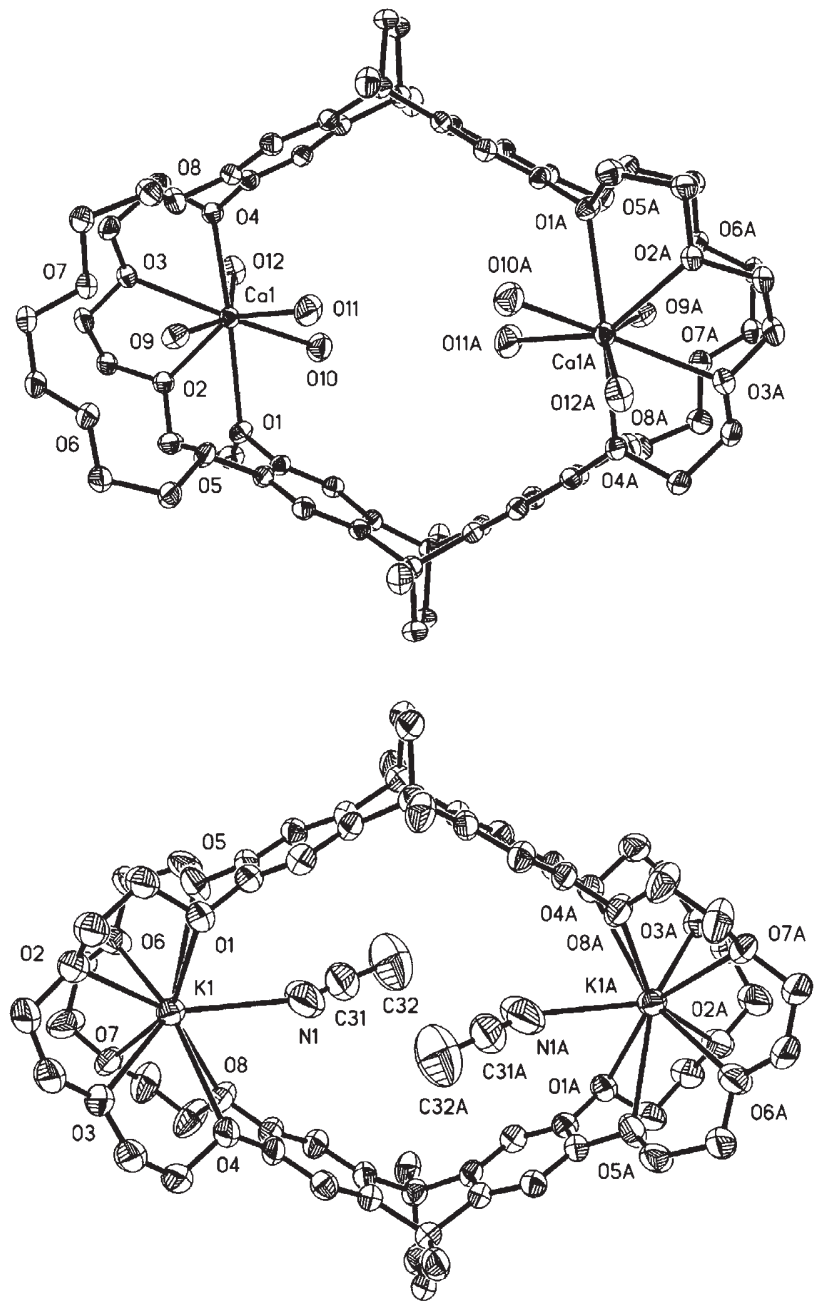

Figure 7. ORTEP plots of the solid state structures of $\left[\mathbf{1} \supset \mathrm{Ca}_{2}\right]^{4+} \cdot 8 \mathrm{H}_{2} \mathrm{O}$ (top) and $\left[\mathbf{1} \supset \mathrm{K}_{2}\right]^{2+} \cdot 2 \mathrm{MeCN}$ (bottom).

ed, were obtained from commercial sources. Anhydrous $\mathrm{CH}_{2} \mathrm{Cl}_{2}$ and MeCN were obtained by distillation from $\mathrm{CaH}_{2}$ under $\mathrm{N}_{2}$. Reactions were conducted under $\mathrm{N}_{2}$ or Ar atmospheres. Thin-layer chromatography (TLC) was performed on Merck $0.25 \mathrm{~mm}$ silica gel (Merck Art. 5715). Column chromatography was undertaken over Kieselgel 60 (Merck, 70230 mesh). Melting points are determined by Fargo MP-2D melting point apparatus. Fluorescence spectra were recorded on Hitachi F-4500. In NMR spectra, the deuterated solvent was used as the lock, while either the solvent's residual protons or TMS was employed as the internal standard. Chemical shifts are reported in parts per million (ppm). Multiplicities are given as s (singlet), $\mathrm{d}$ (doublet), $\mathrm{t}$ (triplet), q (quartet), $\mathrm{m}$ (mutiplet), and br (broad).

X-ray crystallographic analysis: CCDC-294241, CCDC-294242, and CCDC-294243 contain the supplementary crystallographic data for $[\mathbf{1} \supset \mathrm{DMDAP}]\left[\mathrm{PF}_{6}\right]_{2} \cdot \mathrm{H}_{2} \mathrm{O}, \quad\left[\mathbf{1} \supset \mathrm{K}_{2}\right]\left[\mathrm{PF}_{6}\right]_{2} \cdot 4 \mathrm{MeCN}, \quad$ and $\quad\left[\left(\mathbf{1} \supset \mathrm{Ca}_{2}\right]-\right.$ $\left[\mathrm{ClO}_{4}\right]_{4} \cdot 8 \mathrm{H}_{2} \mathrm{O} \cdot 2 \mathrm{CH}_{2} \mathrm{Cl}_{2}$, respectively, contain the supplementary crystallographic data for this paper. These data can be obtained free of charge from The Cambridge Crystallographic Data Centre via www.ccdc.cam.ac.uk/data_request/cif.

Tetraol 4: A mixture of $\mathrm{K}_{2} \mathrm{CO}_{3}(13 \mathrm{~g}, 94.2 \mathrm{mmol}), 2$ (2.6 g, $\left.8.6 \mathrm{mmol}\right)$, and $3(11.7 \mathrm{~g}, 38.5 \mathrm{mmol})$ in $\mathrm{CH}_{3} \mathrm{CN}(150 \mathrm{~mL})$ was heated under reflux for $48 \mathrm{~h}$. The crude product obtained after evaporation of the organic solvent was partitioned between $\mathrm{CH}_{2} \mathrm{Cl}_{2}(500 \mathrm{~mL})$ and $\mathrm{H}_{2} \mathrm{O}(500 \mathrm{~mL})$; the organic layer was collected, dried $\left(\mathrm{MgSO}_{4}\right)$, and concentrated to afford a 
yellow liquid (4.2 g). This crude material was used directly in the next reaction without purification.

Tetrakistosylate 5: A solution of $\mathrm{TsCl}(4.9 \mathrm{~g}, 25.7 \mathrm{mmol})$ in $\mathrm{CH}_{2} \mathrm{Cl}_{2}$ $(25 \mathrm{~mL})$ was added over $10 \mathrm{~min}$ to a solution of tetraol $4(4.2 \mathrm{~g}$, $5.0 \mathrm{mmol})$ and triethylamine $(3.6 \mathrm{~mL}, 25.7 \mathrm{mmol})$ in $\mathrm{CH}_{2} \mathrm{Cl}_{2}(50 \mathrm{~mL})$ at $0{ }^{\circ} \mathrm{C}$. The mixture was slowly warmed to room temperature, stirred for a further $12 \mathrm{~h}$, and then partitioned between $\mathrm{CH}_{2} \mathrm{Cl}_{2}(300 \mathrm{~mL})$ and $\mathrm{H}_{2} \mathrm{O}$ $(300 \mathrm{~mL})$. The organic layer was separated, dried $\left(\mathrm{MgSO}_{4}\right)$, concentrated, and purified $\left(\mathrm{SiO}_{2} ; \mathrm{EtOAc} /\right.$ hexane, 7:3) to afford the tetrakistosylate $\mathbf{5}$ as a pale-yellow liquid $(2.5 \mathrm{~g}, 35 \%) .{ }^{1} \mathrm{H}$ NMR $\left(400 \mathrm{MHz}, \mathrm{CDCl}_{3}\right): \delta=1.52$ $(\mathrm{s}, 4 \mathrm{H}), 1.83(\mathrm{~s}, 6 \mathrm{H}), 2.40(\mathrm{~s}, 12 \mathrm{H}), 3.55-3.80(\mathrm{~m}, 32 \mathrm{H}), 4.00-4.15(\mathrm{~m}$, $16 \mathrm{H}), 6.85(\mathrm{~s}, 4 \mathrm{H}), 7.29(\mathrm{~d}, J=8 \mathrm{~Hz}, 8 \mathrm{H}), 7.76 \mathrm{ppm}(\mathrm{d}, J=8 \mathrm{~Hz}, 8 \mathrm{H})$; ${ }^{13} \mathrm{C}$ NMR $\left(100 \mathrm{MHz}, \mathrm{CDCl}_{3}\right): \delta=19.0,21.9,36.4,41.4,68.7,69.3,69.6$, 70.0, 70.6, 70.7, 109.1, 127.5, 129.4, 132.4, 139.7, 144.2, 145.9 ppm; HR-MS (FAB): $m / z$ calcd for $\mathrm{C}_{70} \mathrm{H}_{91} \mathrm{O}_{24} \mathrm{~S}_{4}: 1443.4783[M+\mathrm{H}]^{+}$; found: 1443.4794. Molecular cage 1: $\mathrm{K}_{2} \mathrm{CO}_{3}(5.3 \mathrm{~g}, 38.4 \mathrm{mmol})$ was added to a solution of biscatechol 2 (276 mg, $0.93 \mathrm{mmol})$ and tetrakistosylate 5 (1.3 g, $0.93 \mathrm{mmol})$ in $\mathrm{CH}_{3} \mathrm{CN}(100 \mathrm{~mL})$ at room temperature. The mixture was heated under reflux for 12 days and then the organic solvent was evaporated under reduced pressure. The crude product was partitioned between $\mathrm{CH}_{2} \mathrm{Cl}_{2}(250 \mathrm{~mL})$ and $\mathrm{H}_{2} \mathrm{O}(250 \mathrm{~mL})$ and then the organic layer was collected, dried $\left(\mathrm{MgSO}_{4}\right)$, and concentrated to give a yellow solid, which was purified $\left(\mathrm{SiO}_{2} ; \mathrm{MeOH} / \mathrm{CH}_{2} \mathrm{Cl}_{2}, 5: 95\right)$ to afford the molecular cage 1 as a white solid $(78 \mathrm{mg}, 8 \%)$. M.p. $>288^{\circ} \mathrm{C}$ (decomp); ${ }^{1} \mathrm{H}$ NMR $\left(400 \mathrm{MHz}, \mathrm{CDCl}_{3}\right): \delta=1.50(\mathrm{~s}, 8 \mathrm{H}), 1.77(\mathrm{~s}, 12 \mathrm{H}), 3.60-3.90(\mathrm{~m}, 32 \mathrm{H})$, $3.95-4.10(\mathrm{~m}, 16 \mathrm{H}), 6.72 \mathrm{ppm}(\mathrm{s}, 8 \mathrm{H}) ;{ }^{13} \mathrm{C} \mathrm{NMR}\left(100 \mathrm{MHz}, \mathrm{CDCl}_{3}\right): \delta=$ 19.0, 36.3, 41.3, 69.8, 69.9, 71.0, 108.3, 139.5, 145.7 ppm; HR-MS (FAB): $m / z$ calcd for $\mathrm{C}_{60} \mathrm{H}_{77} \mathrm{O}_{16}: 1053.5212[M+\mathrm{H}]^{+}$; found: 1053.5216 .

\section{Acknowledgements}

This study was supported by the National Science Council, Taiwan (NSC94-2113M-002-011).

[1] a) A. P. de Silva, H. Q. N. Gunaratne, T. Gunnlaugsson, A. J. M. Huxley, C. P. McCoy, J. T. Rademacher, T. E. Rice, Chem. Rev. 1997, 97, 1515-1566; b) D. T. McQuade, A. E. Pullen, T. M. Swager, Chem. Rev. 2000, 100, 2537-2574; c) G. W. Gokel, W. M. Leevy, M. E. Weber, Chem. Rev. 2004, 104, 2723-2750.

[2] a) A. L. Lehninger, Principles of Biochemistry, CBS, Delhi, 1984; b) L. Stryer, Biochemistry, 3rd ed., Freeman, New York, 1988.

[3] a) A. Minta, R. Y. Tsien, J. Biol. Chem. 1989, 264, 19449-19457; b) A. P. de Silva, H. Q. N. Gunaratne, J. Chem. Soc. Chem. Commun. 1990, 186-188; c) A. P. de Silva, H. Q. N. Gunaratne, G. E. M. Maguire, J. Chem. Soc. Chem. Commun. 1994, 1213-1214; d) N. R. Cha, S. Y. Moon, S.-K. Chang, Tetrahedron Lett. 2003, 44, 8265-8268; e) Y. Nakahara, T. Kida, Y. Nakatsuji, M. Akashi, J. Org. Chem. 2004, 69, 4403-4411; f) E. Arunkumar, A. Ajayaghosh, J. Daub, J. Am. Chem. Soc. 2005, 127, 3156-3164.

[4] a) A. P. de Silva, I. M. Dixon, H. Q. N. Gunaratne, T. Gunnlaugsson, P. R. S. Maxwell, T. E. Rice, J. Am. Chem. Soc. 1999, 121, $1393-$ 1394; b) K. Rurack, W. Rettig, U. Resch-Genger, Chem. Commun. 2000, 407-408; c) B. Witulski, M. Weber, U. Bergsträsser, J.-P. Desvergne, D. M. Bassani, H. Bouas-Laurent, Org. Lett. 2001, 3, 14671470; d) H. He, M. A. Mortellaro, M. J. P. Leiner, R. J. Fraatz, J. K. Tusa, J. Am. Chem. Soc. 2003, 125, 1468-1469.

[5] a) F. Fages, J.-P. Desvergne, H. Bouas-Laurent, J.-M. Lehn, Y. Barrans, P. Marsau, M. Meyer, A.-M. Albrecht-Gary, J. Org. Chem. 1994, 59, 5264-5271; b) D. Y. Sasaki, D. R. Shnak, D. W. Pack, F. H. Arnold, Angew. Chem. 1995, 107, 994-996; Angew. Chem. Int. Ed. Engl. 1995, 34, 905-907; c) J. Strauss, J. Daub, Org. Lett. 2002, 4, 683-686; d) J.-H. Liao, C.-T. Chen, J.-M. Feng, Org. Lett. 2002, 4, $561-564$.
[6] Most of these supramolecular sensing ensembles comprise acyclic receptors and indicators; see: S. L. Wiskur, H. Ait-Haddou, J. J. Lavigne, E. V. Anslyn, Acc. Chem. Res. 2001, 34, 963-972.

[7] a) A. Ueno, Supramol. Sci. 1996, 3, 31-36; b) T. Hayashita, A. Yamauchi, A.-J. Tong, J. C. Lee, B. D. Smith, N. Teramae, J. Inclusion Phenom. Macrocyclic Chem. 2004, 50, 87-94.

[8] Because of insufficiently strong binding between the host and the indicator-that is, to avoid any possible background signal from the free indicator-supramolecular optical probes were generally prepared as solutions containing millimolar concentrations of the host and micromolar concentrations of the indicator. See: a) A. P. Bisson, V. M. Lynch, M.-K. C. Monahan, E. V. Anslyn, Angew. Chem. 1997, 109, 2435-2437; Angew. Chem. Int. Ed. Engl. 1997, 36, 2340-2342; b) K. Niikura, A. P. Bisson, E. V. Anslyn, J. Chem. Soc. Perkin Trans. 2 1999, 1111-1114; c) Ref. 7b.

[9] Noncovalent molecular cages have been prepared; see: a) M. Kim, G. W. Gokel, J. Chem. Soc. Chem. Commun. 1987, 1686-1688; b) J. M. C. Kerckhoffs, F. W. B. van Leeuwen, A. L. Spek, K. Kooijman, M. Crego-Calama, D. N. Reinhoudt, Angew. Chem. 2003, 115, 5895-5900; Angew. Chem. Int. Ed. 2003, 42, 5717-5722; c) M. Yoshizawa, S. Miyagi, M. Kawano, K. Ishiguro, M. Fujita, J. Am. Chem. Soc. 2004, 126, 9172-9173; cryptand-type host molecules may be considered as the simplest covalently linked molecular cages; see: d) K. A. Nielsen, J. O. Jeppesen, E. Levillain, N. Thorup, J. Becher, Org. Lett. 2002, 4, 4189-4192; e) D. F. Perkins, L. F. Lindoy, G. V. Meehan, P. Turner, Chem. Commun. 2004, 152-153; f) M. Bonizzoni, L. Fabbrizzi, G. Piovani, A. Taglietti, Tetrahedron 2004, 60, 11159-11162; cryptophanes, carcerands, and hemicarcerands may also be considered as covalently linked molecular cages; see: g) A. Collet, J.-P. Dutasta, B. Lozach, J. Canceil, Top. Curr. Chem. 1993, 165, 103-130; h) A. Jasat, J. C. Sherman, Chem. Rev. 1999, 99, 931-967; i) R. Warmuth, Acc. Chem. Res. 2001, 34, 95105

[10] a) T. L. Tarnowski, D. J. Cram, J. Chem. Soc. Chem. Commun. 1976, 661-663; b) R. C. Helgeson, T. L. Tarnowski, D. J. Cram, J. Org. Chem. 1979, 44, 2538-2550.

[11] P. R. Ashton, S. E. Boyd, A. Brindle, S. J. Langford, S. Menzer, L. Perez-Garcia, J. A. Preece, F. M. Raymo, N. Spencer, J. F. Stoddart, A. J. P. White, D. J. Williams, New J. Chem. 1999, 23, 587-602.

[12] A cylindrical host comprising two linked bis(meta-phenylene)[26]crown- 8 moieties has been prepared; its two crown ether units form complexes with two paraquat guests independently. See: F. Huang, L. N. Zakharov, A. L. Rheingold, M. Ashraf-Khorassani, H. W. Gibson, J. Org. Chem. 2005, 70, 809-813.

[13] J. R. Lakowicz, Principle of Fluorescence Spectroscopy, 2nd ed., Plenum, New York, 1999.

[14] V. Balzani, A. Credi, S. J. Langford, A. Prodi, J. F. Stoddart, M. Venturi, Supramol. Chem. 2001, 13, 303-311.

[15] P. Thuéry, B. Masci, Supramol. Chem. 2003, 15, 95-99.

[16] K. A. Connors, Binding Constants, Wiley, New York, 1987.

[17] If we assume that the observation of no free species in the ${ }^{1} \mathrm{H}$ NMR spectrum of the equimolar mixture of molecular cage $\mathbf{1}$ and $\mathrm{DMDAP}\left[\mathrm{PF}_{6}\right]_{2}$ at $10 \mu \mathrm{M}$ concentration suggests that the free species presented in the solution are less than $5 \%$, then the binding constant $\left(K_{\mathrm{a}}\right)$ between molecular cage 1 and DMDAP $\left[\mathrm{PF}_{6}\right]_{2}$ may be estimated to be as high as $3.8 \times 10^{7} \mathrm{M}^{-1}$.

[18] a) P. L. Anelli, P. R. Ashton, R. Ballardini, V. Balzani, M. Delgado, M. T. Gandolfi, T. T. Goodnow, A. E. Kaifer, D. Philp, M. Pietraszkiewicz, L. Prodi, M. V. Reddington, A. M. Z. Slawin, N. Spencer, J. F. Stoddart, C. Vicent, D. J. Williams, J. Am. Chem. Soc. 1992, 114, 193-218; b) P.-T. Chiang, P.-N. Cheng, C.-F. Lin, Y.-H. Liu, C.-C. Lai, S.-M. Peng, S.-H. Chiu, Chem. Eur. J. 2006, 12, 865-876.

[19] Crystal data for [1 $\supset$ DMDAP $]\left[\mathrm{PF}_{6}\right]_{2} \cdot \mathrm{H}_{2} \mathrm{O}: M_{\mathrm{r}}=1595.5$, triclinic, space group $P \overline{1}, a=11.9376(10), b=13.7324(12), c=14.8477(14) \AA$, $\alpha=65.109(4), \beta=72.059(4), \gamma=79.729(6)^{\circ} \quad V=2097.2(3) \AA^{3}, Z=1$, $\rho_{\text {calcd }}=1.263 \mathrm{~g} \mathrm{~cm}^{-3}, \mu\left(\mathrm{Mo}_{\mathrm{K} \alpha}\right)=0.141 \mathrm{~cm}^{-1}, \quad T=295 \mathrm{~K}$, orange red plates; 7312 independent measured reflections, $F^{2}$ refinement, $R_{1}=$ $0.1338, w R_{2}=0.2919$. 
[20] For practical usage, calcium sensors, which only operate in nonaqueous solvents may need further modification in order to operate in water.

[21] Crystal data for $\left[\mathbf{1} \supset \mathrm{Ca}_{2}\right]\left[\mathrm{ClO}_{4}\right]_{4} \cdot 8 \mathrm{H}_{2} \mathrm{O} \cdot 2 \mathrm{CH}_{2} \mathrm{Cl}_{2}: M_{\mathrm{r}}=1845.2$, triclinic, space group $P \hat{1}, a=9.0650(1), b=14.1963(1), c=17.2977(2) \AA$, $\alpha=101.5440(5), \beta=91.7530(5), \gamma=108.3000(5)^{\circ} \quad V=2060.23(4) \AA^{3}$, $Z=1, \rho_{\text {calcd }}=1.487 \mathrm{~g} \mathrm{~cm}^{-3}, \mu\left(\mathrm{Mo}_{\mathrm{K} \alpha}\right)=0.489 \mathrm{~cm}^{-1}, T=295 \mathrm{~K}$, colorless plates; 9416 independent measured reflections, $F^{2}$ refinement, $R_{1}=$ $0.0665, w R_{2}=0.1975$. A triethylene glycol ligand adopting a crown ether like conformation while complexing with a $\mathrm{Ca}^{2+}$ center, with water and other ligands in a pentagonal bipyramidal geometry, has been observed previously. See: a) R. D. Rogers, A. H. Bond, Acta Crystallogr. Sect. C 1992, 48, 1782-1785; b) G. Hundal, M. Martinez-Ripoll, M. S. Hundal, N. S. Poonia, Acta Crystallogr. Sect. C 1996, 52, 789-792.
[22] Crystal data for $\left[1 \mathrm{1}_{2}\right]\left[\mathrm{PF}_{6}\right]_{2} \cdot 4 \mathrm{CH}_{3} \mathrm{CN}: M_{\mathrm{r}}=1585.56$, monoclinic, space group $P 2_{1} / n, a=14.2301(4), b=13.6183(4), c=21.8428(7) \AA$, $\beta=98.336(2)^{\circ}, \quad V=4188.2(2) \AA^{3}, \quad Z=2, \quad \rho_{\text {calcd }}=1.257 \mathrm{~g} \mathrm{~cm}^{-3}, \quad \mu$ $\left(\mathrm{Mo}_{\mathrm{K} \alpha}\right)=0.237 \mathrm{~cm}^{-1}, \mathrm{~T}=295 \mathrm{~K}$, colorless plates; 7367 independent measured reflections, $F^{2}$ refinement, $R_{1}=0.0907, w R_{2}=0.2359$. The solid state structure of a related diester crown ether complexing with $\mathrm{KPF}_{6}$ also reveals a centered $\mathrm{K}^{+}$ion bound through ion-dipole interactions to all eight ether oxygen atoms of the crown ether; see: H. W. Gibson, H. Wang, K. Bonrad, J. W. Jones, C. Slebodnick, L. N. Zackharov, A. L. Rheingold, B. Habenicht, P. Lobue, A. E. Ratliff, Org. Biomol. Chem. 2005, 3, 2114-2121.

[23] S. Watanabe, S. Ikishima, T. Matsuo, K. Yoshida, J. Am. Chem. Soc. 2001, 123, 8402-8403.

Received: January 20, 2006 Published online: March 24, 2006 